OPEN ACCESS

Edited by:

Chun Yang,

Nanjing Medical University, China

Reviewed by:

Ji-Chun Zhang,

Jinan University, China

Yimin $\mathrm{Hu}$,

Nanjing Medical University, China

Wen-Tao Liu,

Nanjiing Medical University, China

*Correspondence:

Chao Liu

Chaoliu@xzhmu.edu.cn:

flowingsands@hotmail.com

Specialty section:

This article was submitted to

Perception Science,

a section of the journal

Frontiers in Neuroscience

Received: 16 December 2020

Accepted: 27 January 2021

Published: 24 February 2021

Citation:

Ji M-J, Yang J, Gao Z-Q, Zhang L

and Liu C (2021) The Role of the

Kappa Opioid System in Comorbid

Pain and Psychiatric Disorders:

Function and Implications.

Front. Neurosci. 15:642493.

doi: 10.3389/fnins.2021.642493

\section{The Role of the Kappa Opioid System in Comorbid Pain and Psychiatric Disorders: Function and Implications}

\author{
Miao-Jin Ji', Jiao Yang ${ }^{1}$, Zhi-Qiang Gao' ${ }^{2}$ Liang Zhang ${ }^{3}$ and Chao Liu' ${ }^{\text {* }}$ \\ 1 Jiangsu Province Key Laboratory of Anesthesiology and Jiangsu Province Key Laboratory of Anesthesia and Analgesia \\ Application Technology, School of Anesthesiology, Xuzhou Medical University, Xuzhou, China, ${ }^{2}$ Jiangsu Province Key \\ Laboratory of New Drug Research and Clinical Pharmacy, School of Pharmacy, Xuzhou Medical University, Xuzhou, China, \\ ${ }^{3}$ Department of Neurology, Affiliated Hospital of Qingdao University, Qingdao, China
}

Both pain and psychiatric disorders, such as anxiety and depression, significantly impact quality of life for the sufferer. The two also share a strong pathological link: chronic pain-induced negative affect drives vulnerability to psychiatric disorders, while patients with comorbid psychiatric disorders tend to experience exacerbated pain. However, the mechanisms responsible for the comorbidity of pain and psychiatric disorders remain unclear. It is well established that the kappa opioid system contributes to depressive and dysphoric states. Emerging studies of chronic pain have revealed the role and mechanisms of the kappa opioid system in pain processing and, in particular, in the associated pathological alteration of affection. Here, we discuss the key findings and summarize compounds acting on the kappa opioid system that are potential candidates for therapeutic strategies against comorbid pain and psychiatric disorders. Keywords: kappa opioid system, pain-induced negative affect, cormorbid pain and psychiatric disorders, KOR
agonists, KOR antagonists

\section{INTRODUCTION}

Untreated negative affect induced by chronic pain largely drives vulnerability to mood disorders. Epidemiological evidence suggests that the prevalence of depression ranges from 30 to $80 \%$ in different pain etiologies (Bair et al., 2003; Howe and Sullivan, 2014), and chronic pain is one of the chief complaints in $65 \%$ of patients with treatment-resistant depression (Bair et al., 2003). Moreover, clinical studies have shown that comorbid chronic pain and depression mutually promote disease severity: such patients exhibit a poorer prognosis than those with only one disorder (Scherrer et al., 2016; Sullivan, 2016). Uncovering the mechanisms underlying comorbidity is therefore essential for proper treatment of these patients.

Owing to the complex pathogenesis of comorbid pain and psychiatric disorders, no existing animal model can mimic all of the relevant aspects. However, in recent years, scientists have begun to address the links between the two by dividing pain into sensory and affective dimensions and using behavioral paradigms to analyze affective states in animal models of chronic pain. The results have shown that many types of chronic pain induce aversion phenotypes in animals, including decreased motivation in goal-directed behaviors, conditioned place aversion, longer immobility times in the forced swim test, and decreased time in the light compartment during the light/dark test (Leite-Almeida et al., 2015). These behavioral observations in animals may reflect some of the 
psychiatric symptoms observed in patients. Thus, uncovering the mechanisms underlying pain-induced aversive states in animals may be the key to understanding the comorbid relationship between chronic pain and mood disorders.

Opioids are the most effective prescription for relieving chronic pain. The classic opioid receptors, the mu opioid receptor (MOR), the delta opioid receptor (DOR), and the kappa opioid receptor (KOR), all belong to the class A (rhodopsinlike) $\gamma$-subfamily of seven-transmembrane $G$ protein-coupled receptors (GPCRs), which forms the largest family of targets for current therapeutics. A complete GPCR system involves ligands, a receptor, and transducers. Upon binding to extracellular ligands, GPCRs often undergo a conformational change that causes GDP to be exchanged for GTP bound to G $\alpha$, leading to dissociation of $\mathrm{G} \alpha$ and the G $\beta \gamma$ dimer. Both the activated GTPbound $\mathrm{G} \alpha$ and the $\mathrm{G} \beta \gamma$ dimer can transduce signals via second messengers or transducers such as CAMP, inositol trisphosphate $\left(\mathrm{IP}_{3}\right)$, and diacylglycerol (DAG). After agonist activation, GPCRs are phosphorylated by $G$ protein-coupled receptor kinases (GRKs), which recruit arrestin to the original G protein-binding sites. This process makes GPCRs lose the ability to respond to ligand binding, which is referred to as "receptor desensitization." Long-term use of opioids has been shown to cause addiction and increase the risk of depression (Crofford, 2010; Salas et al., 2017), which may be mediated by the desensitization of opioid receptors. These inherent adverse effects limit the clinical application of opioids. The classic theory of addiction hypothesizes that all addictive drugs enhance dopamine (DA) transmission in the reward circuitry. Interestingly, unlike the excitatory effects of MORs and DORs, KORs normally inhibit neuronal activity and neurotransmission (Tejeda et al., 2013, 2017). Systemic activation of KORs elicits analgesia similar to that induced by MOR activation but with fewer incidences of euphoria and reinforcement. Studies have demonstrated that MORs and KORs have opposite effects on the regulation of motivational processes (Spanagel et al., 1992). These features make KOR a promising drug target to develop non-addictive analgesics.

However, kappa opioid analgesics produce dysphoric effects and psychotomimesis in humans (Walsh et al., 2001; Chartoff and Mavrikaki, 2015) and elicit place aversion and depressivelike affective behaviors in rodents (Chavkin and Koob, 2016; Darcq and Kieffer, 2018). In fact, among the three classical opioid receptor systems, KORs in concert with their primary endogenous ligand, dynorphin, are most heavily implicated in aversion and psychiatric disorders such as depression and anxiety. Increased dynorphin release and KOR expression have been observed in suicidal individuals and preclinical models of neuropsychiatric disorders (Peckys and Hurd, 2001). KOR antagonists are capable of overcoming the pro-depression and anxiogenic effects of chronic or acute stressors (Carr et al., 2010; Browne et al., 2018), and a number of KOR antagonists are already in clinical trials for the treatment of psychiatric disorders (Lowe et al., 2014; Buda et al., 2015; Chavkin and Martinez, 2015). At the same time, KOR expression and function are significantly altered in various chronic pain models, such as peripheral nerve injury (Liu et al., 2019) and chronic constriction injury (Wawrzczak-Bargiela et al., 2020). However, whether the dynorphin/KOR (Dyn/KOR) system is directly involved in pain and psychiatric disorders remains unclear. Considering the opposing effects of KOR activation on chronic pain and depression, how to properly harness KOR agonists as analgesics while avoiding their side effects still needs to be determined. Here, we discuss the function of the Dyn/KOR system and its clinical implications and summarize promising candidates for the treatment of comorbid pain and psychiatric disorders.

\section{KOR EXPRESSION AND SIGNALING}

The Dyn/KOR system is distributed throughout different brain regions, with KORs expressed in various types of mood-related neurons including serotonergic neurons (Land et al., 2009), corticotropin-releasing factor (CRF) neurons (Marchant et al., 2007), and DA neurons (Liu et al., 2019; Figure 1). It is widely accepted that KOR activation produces negative affect, both in human beings and in rodents (Martinez et al., 2019). Moreover, ablation of KORs from DA neurons or basolateral amygdala (BLA) glutamatergic terminals in the medial prefrontal cortex produces an anxiolytic phenotype (Margolis et al., 2006; Lowery-Gionta et al., 2018), suggesting that the KOR system is critical for the expression of negative affect. Interestingly, besides the regions mentioned above, high levels of the precursor prodynorphin are detected in the periaqueductal gray, the striatum, and the bed nucleus of the stria terminalis (BNST) (Marchant et al., 2007). Given that elements of the Dyn/KOR system are present in the main circuitry involved in both pain processing and affective/motivational systems, it seems likely that the Dyn/KOR system contributes to the aversive nature of chronic pain. At the primary afferent level, KOR is expressed in a transcriptionally distinct subset of peptidergic afferents that strongly express the genes encoding calcitonin gene-related peptide (CGRP) and substance $P$, and in two populations of low-threshold mechanoreceptors; however, there are very low levels of KORs in cool-sensing neurons and proprioceptors (Snyder et al., 2018).

KORs are located both presynaptically and postsynaptically and play different roles. For example, in the dorsal raphe nucleus (DRN), acute KOR activation inhibits serotonergic neuronal excitability through presynaptic inhibition of excitatory synaptic transmission and postsynaptic activation of ion channels (Lemos et al., 2012). Within the BNST, KORs provide inhibitory control over presynaptic GABAergic signaling (Li et al., 2012; Hwa et al., 2020). Generally, presynaptic KORs modulate monoaminergic and glutamatergic neurotransmitter release whereas postsynaptic KORs hyperpolarize the cell membrane and inhibit neuronal excitation.

Like other GPCRs, most KOR signaling can be divided into two types: classical KOR signal-transduction pathways and KORinduced arrestin-p38 mitogen-activated protein kinase (arrestinMAPK) cascades (Figure 2). In the first signaling pathway, G $\beta \gamma$ released from the $\mathrm{G} \alpha$ subunit binds directly to ion channels and plays an inhibitory role by activating $G$ protein-gated inwardly rectifying potassium channels $\left(\mathrm{K}_{i r} 3 \mathrm{~s}\right)$ or blocking voltage-gated $\mathrm{Ca}^{2+}$ channels (Rusin et al., 1997; Sadja et al., 2003). Meanwhile, 


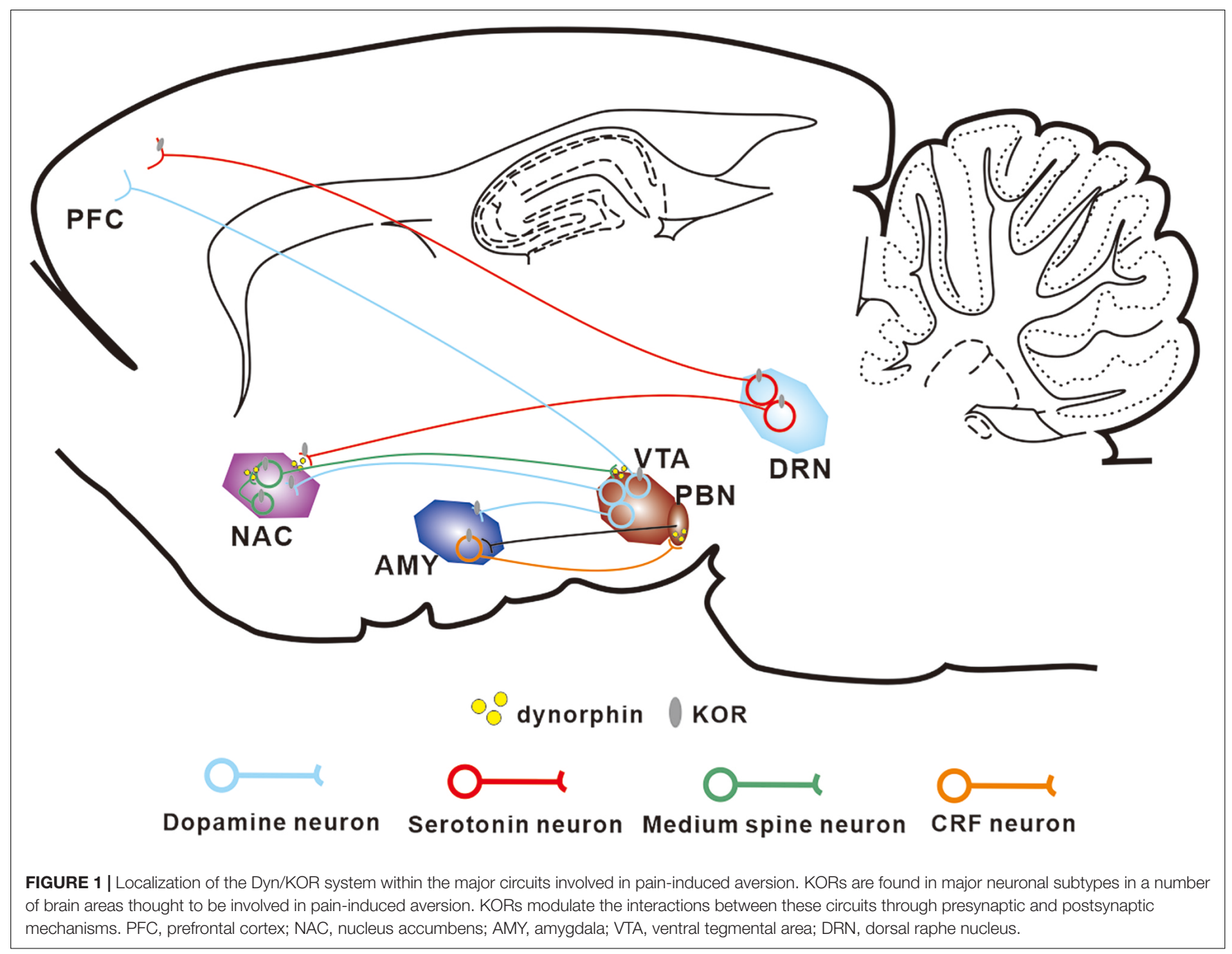

G $\alpha$ decreases cAMP and causes ERK phosphorylation. These inhibitory effects have been demonstrated in various cell types ranging from hippocampal granule cells to spinal cord motor neurons, resulting in decreased transmission of nociceptive stimuli at multiple levels of the pain pathways and a profound reduction in the perception of pain. However, several studies have reported excitatory effects of KOR activation, particularly with chronic KOR agonist treatment. This suggests that under some circumstances KORs can activate stimulatory $G$ proteins and upregulate adenylyl cyclase, thus contributing to heterologous tolerance of opioids and physical dependence (Raynor et al., 1994; Avidor-Reiss et al., 1997).

In the second signaling pathway, KORs recruit $\beta$-arrestin scaffolding proteins after agonist-induced GRK3 phosphorylation of the C-terminal intracellular domain. It has been reported that phosphorylation at KOR serine 369 in rodents (Land et al., 2009) or serine 358 in humans (Li et al., 2002) leads to KOR desensitization and internalization. The recruited arrestin mediates p38 MAPK and ERK1/2 phosphorylation (Bruchas et al., 2008; McLennan et al., 2008) and has been observed to occur following behavioral stress.
The $\beta$-arrestin signaling pathway has been demonstrated to contribute to KOR-induced aversion, dysphoria, and sedation, but not to KOR-induced analgesia. Thus, functionally selective KOR agonists, termed "biased agonists," may be able to selectively avoid p38 MAPK activation and hold promise for pain relief without side effects (as detailed in the section "Drug Candidates and Future Directions," below). Possible substrates of the KOR-activated p38 MAPK pathway include ion channels (Nav1.8, Kir3.1), serotonin transporters (SERT), and transcription factors (zif268, elF4B) (Hudmon et al., 2008; Steiner et al., 2008; Guan et al., 2010; Ruan et al., 2010). Regulation of these effectors may explain the characteristics of the behavioral responses seen with KORinduced p38 activation. Arrestin-dependent KOR-induced ERK1/2 phosphorylation occurs $2 \mathrm{~h}$ after agonist treatment and is known as late-phase ERK1/2 phosphorylation; early phase ERK1/2 activation occurs 5-15 min after agonist treatment and depends on the G $\beta \gamma$ subunit. Potential effects of KOR-induced early phase ERK1/2 activation include increases in AMPA receptor cell surface expression, growth of dendritic spines, and regulation of CREB activation. Interestingly, KORs can 


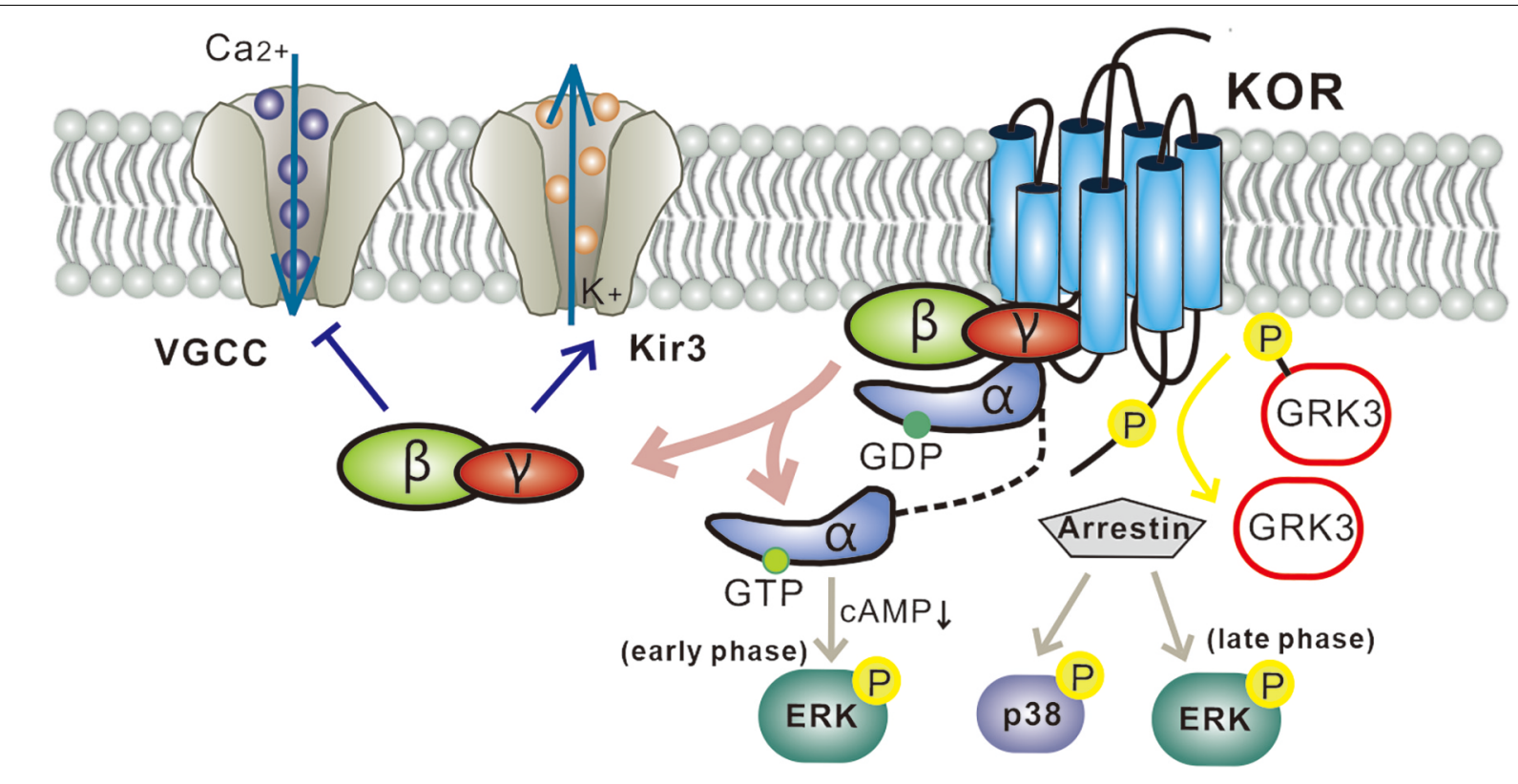

\section{G protein-dependent pathway Analgesia}

\section{Arrestin-dependent pathway Side effects}

FIGURE 2 | Different downstream KOR signaling pathways mediate distinct functions. The G protein-mediated KOR signaling pathway plays an inhibitory role by activating $G$ protein-gated inwardly rectifying potassium channels $\left(\mathrm{K}_{i} 3 \mathrm{~s}\right)$ and blocking voltage-gated $\mathrm{Ca}^{2+}$ channels. $\mathrm{G} \alpha$ mediates a decrease in cAMP via $\mathrm{G} \alpha \mathrm{a}$ and causes ERK phosphorylation (early phase: 5-15 min after agonist treatment). This classic pathway mediates the analgesia induced by KOR ligands. Separately, KOR activation also recruits arrestin and leads to the activation of several kinase cascades including ERK (late phase: $2 \mathrm{~h}$ after agonist treatment) and p38, which mediate the adverse effects induced by KOR ligands. Biased KOR agonism of the $G$ protein-dependent pathway should lead to effective analgesia with fewer side effects. Arrows: activation steps, T lines: inhibition of function. Kir3, G protein-gated inwardly rectifying potassium channel; VGCC, voltage-gated $\mathrm{Ca}^{2+}$ channel; P, phosphorylation; cAMP, cyclic adenosine monophosphate; GRK3, G protein-coupled receptor kinase.

activate different signaling cascades within a single brain region (Hjelmstad and Fields, 2003).

\section{Dyn/KOR AND THE NEURAL CIRCUITS INVOLVED IN PAIN-INDUCED NEGATIVE AFFECT}

\section{Mesolimbic Circuitry}

Recent studies on pain and depression show that decreased motivation in goal-directed behavior is a characteristic feature of pain-induced negative affect (Cahill et al., 2014; Ji et al., 2018; Liu et al., 2019). Thus, the mesolimbic circuitry, which is also known as the reward circuitry, may play a critical role in driving pain-induced negative affective states. This circuitry is composed of DA neurons in the ventral tegmental area (VTA) and their projections to forebrain limbic structures such as the nucleus accumbens (NAc) and prefrontal cortex (PFC).

VTA DA neurons receive strong dynorphin projections from the striatum, the lateral hypothalamus, the central nucleus of the amygdala (CeA), and the BNST (Fallon et al., 1985; Kaufling et al., 2017). Recently, Cahill's lab reported that chronic pain caused an increase in KOR mRNA (Oprk1) expression in DA neurons only in male mice and that pain-induced aversive states were increased by a KOR agonist in male but not female mice (Liu et al., 2019). The authors attributed the observed sex differences to complex hormonal and sex-chromosome factors, which are known to influence the depressive and anti-nociceptive effects of KOR in non-pain models (Russell et al., 2014; Abraham et al., 2018; Zhang et al., 2018). Liu et al. (2019) also reported that ablation of KORs from DA neurons using AAV-TH-cre virus in KOR loxP mice prevented pain-induced aversive states without affecting the sensory dimension of chronic pain (Liu et al., 2019). KORs are distributed in both the somatodendritic and terminal regions of VTA DA neurons (Tejeda et al., 2013). Activation of KORs located in the terminals of DA neurons inhibits DA release in efferents (Spanagel et al., 1992), but activation of KORs located in VTA cell bodies appears to have pathway-dependent effects, hyperpolarizing the dopaminergic projection to the $\mathrm{mPFC}$ and amygdala but not the projection to the NAc core (Margolis et al., 2006, 2008). Circuit DA dynamics are also shaped by Dyn/KORinduced presynaptic inhibition of excitatory neurotransmission and GABA release onto VTA DA neurons (Graziane et al., 2013). Although many findings indicate that inhibition of the DA output is the mechanism underlying KOR agonist-induced 
aversion, there is evidence to suggest that the recruitment of p38 MAPK signaling in DA neurons is critical. Conditional knockout of p38 signaling in DA neurons did not abolish the ability of a KOR agonist to inhibit DA release but did block KORmediated aversion (Ehrich et al., 2015). Indeed, DA release is not decreased in many pain paradigms (Navratilova et al., 2012; Xie et al., 2014), such as PGE2-induced hyperalgesia (Vergara et al., 2020), that produce aversive affect in behavioral tests. Therefore, the hypothesis that the recruitment of p38 MAPK signaling in DA neurons is more important than DA transmission alteration in KOR-mediated aversion seems to work in pain states, but further work is needed to identify the mechanism underlying the effects of the VTA Dyn/KOR system in paininduced negative emotions.

Unlike in the VTA, which receives dynorphin projections from other nuclei, dynorphin is released locally in the NAc from medium spine neurons (MSNs). Massaly et al. (2019) reported an increase in local dynorphin tone in the NAc shell in inflammatory pain, resulting from pain-induced selective disinhibition of dynorphin-containing neurons. Similarly, higher levels of Oprk1 mRNA are observed in the NAc in animals with a spared nerve injury (Palmisano et al., 2017). It is noteworthy that the increase in KORs usually occurs during the early phase of neuropathy whereas downregulation of Oprk1 gene expression happens during the late phase, 2 weeks after surgery (Vergara et al., 2020), and may be attributed to internalization and densensitization of KORs. Furthermore, it has been demonstrated recently that KOR blockade in the NAc reverses preclinical measures of injury-induced aversion and anhedonia and that photogenetic activation of dynorphincontaining MSNs is sufficient to lead to negative affective states (Massaly et al., 2019). In paclitaxel-induced neuropathy, an injury-free model, a KOR antagonist injected into NAc reversed paclitaxel-induced anhedonia but not mechanical hypersensitivity (Meade et al., 2020). Together, these results suggest that pain-induced negative affect is mediated via recruitment of the NAc Dyn/KOR system.

\section{Amygdala}

The amygdala circuitry most relevant for pain-related functions includes the BLA, the central nucleus of the amygdala (CeA), and the intercalated cell clusters interposed between them (Thompson and Neugebauer, 2017, 2019). KORs are located on cells in both the BLA and the CeA, and dynorphin is released from distal projections as well as synthesized locally in the lateral subdivision of the CeA (CeL) (Kravets et al., 2015).

Previous studies have demonstrated that chronic pain promotes neuroplasticity mainly in the CeA (Carrasquillo and Gereau, 2008). Interestingly, modulation of the Dyn/KOR system in the CeA induces significant changes in paininduced aversion (Nation et al., 2018; Navratilova et al., 2019) and KORs in the CeA have been linked to negative affective states associated with ongoing pain. Microinjection of a long-lasting KOR antagonist, nor-binaltorphimine (nor$\mathrm{BNI}$ ) into the right $\mathrm{CeA}$ before spinal nerve ligation in rats prevented neuropathic-induced conditioned place preference to intravenous gabapentin, suggesting that nor-BNI eliminated the aversiveness of ongoing pain (Nation et al., 2018). This effect was mediated by blocking the KOR-mediated disinhibition of CeA output neurons involved in neuropathic pain. Similarly, activation of the pathway from the lateral parabrachial nucleus $(\mathrm{PBN})$ to the CeA generates an aversive memory and dynorphin-expressing neurons are required in the process (Chiang et al., 2020). The IPBN is a major target of spinal projection neurons conveying nociceptive input to supraspinal structures. Most of the outputs from the CeA are GABAergic, coexpressing CRF and dynorphin, and project back to the IPBN. Optogenetic stimulation of the CeA-lPBN pathway suppresses acute pain and inhibiting it evokes pain behaviors in naïve animals, but the efficacy of this pathway is suppressed in chronic pain states (Raver et al., 2020). Hence, the CeA-lPBN circuit plays a negative feedback role in response to noxious stimuli under normal conditions but becomes inefficient in chronic pain states, and the Dyn/KOR system in the CeA is necessary for this role.

\section{Dorsal Raphe Nucleus}

The serotonergic system has been the focus of many studies on the relationship between pain and depression. The dorsal raphe nucleus (DRN) is one of the major sources of serotonin (5-HT) in the brain. Administration of complete Freund's adjuvant (CFA) results in sustained inflammatory pain and leads to depression-like behaviors. This model is widely used to induce comorbid pain and depression, which is characterized by depletion of 5-HT and its metabolism-related precursors in the brain (Zhang et al., 2016). Similarly, decreased levels of 5HT are observed in the PFC in rats infused with a cocktail of inflammatory agents into the dura mater, which induces chronic headache and anxiodepressive-like behaviors (Zhang et al., 2017). Furthermore, recent human functional magnetic resonance imaging data show that functional connectivity between the DRN and the CeA is reduced in patients with comorbid depressive symptoms but not in patients with chronic pain only, compared with healthy controls (Zhou et al., 2019). Pharmacological and optogenetic results in animals further implicate a novel pathway involving 5 -HT projections from the DRN to somatostatin-expressing neurons in the CeA in the comorbidity (Zhou et al., 2019).

Previous work indicates that administration of a KOR agonist into the DRN decreases extracellular $5-\mathrm{HT}$ by approximately 30\% (Fuentealba et al., 2010). It has been demonstrated that the Dyn/KOR system modulates serotonin transmission, especially in stress-related behaviors. First, KOR activation in the DRN inhibits the excitatory inputs onto serotoninergic neurons. Second, KORs increase postsynaptic G protein-gated inwardly rectifying potassium channel (GIRK) currents in the DRN. Lastly, KORs mediate the translocation of the serotonin transporter SERT via a p38 MAPK-dependent mechanism. Moreover, repeated stress exposure induces dynorphin release and KOR activation in 5-HT neurons in the DRN (Lemos et al., 2012). As a form of repeated stress, chronic pain may alter the DRNCeA pathway by regulating the Dyn/KOR system in the DRN; however, more clinical and in vivo evidence is needed to fully elucidate the underlying mechanisms. 


\section{DRUG CANDIDATES AND FUTURE DIRECTIONS}

There is no doubt that an analgesic with antidepressant and/or anxiolytic effects is optimal for patients with comorbid pain and mood disorders. However, this has proved to be an elusive goal for clinical and laboratory researchers for many decades. As one of the most commonly used categories of analgesic, opioids and opioid-based therapies may be the key to achieving this goal. Indeed, progress has already been made on several specific compounds targeting KORs for treatment of comorbid pain and psychiatric disorders (detailed in Table 1).

\section{Biased G Protein KOR Agonists}

Upon extracellular ligand binding, GPCRs usually undergo a conformational change that activates heterotrimeric $\mathrm{G}$ proteins, a process that is important for transmitting the required signals. The ability of agonists acting at the same GPCR to preferentially elicit different signaling pathways by stabilizing the receptor in a particular active conformational state is called "biased agonism" or "functional selectivity." The discovery of this phenomenon offers a therapeutic alternative to conventional full KOR agonism, which provides effective analgesia but at the cost of significant side effects including dysphoria, sedation, anxiety, and depression. There is consensus that KOR-coupled G protein signaling is the major pathway for the analgesic effects of KOR agonists whereas the arrestin-p38 MAPK cascade is required for aversion and other effects (Fields, 2011). Thus, biased $\mathrm{G}$ protein KOR agonists are promising compounds for the treatment of chronic pain.

Nalfurafine (TRK-820) was the first biased KOR agonist used in a clinical setting, for medication-resistant pruritus in hemodialysis patients (Kumagai et al., 2010). Recently, it has been reported that co-administration of nalfurafine with morphine beneficially modulates both the analgesic and rewarding properties of morphine in mice. Moreover, the dose of nalfurafine that produced a significant effect in the preclinical study (15 $\mu \mathrm{g} / \mathrm{kg}$ ) was similar to the antipruritic dose in mice, suggesting that the clinical dose may provide adequate analgesic synergy while avoiding significant antitherapeutic effects (Schattauer et al., 2017). Modification of the structural scaffold of salvinorin A (SalA), a potent KOR agonist, has produced several biased ligands, such as mesyl SalB, ethoxymethyl ether SalB (EOM SalB), and 22-thiocyanatosalvinorin A (RB-64). These are better biased G protein agonists for human KOR than SalA or U50,488H, another balanced KOR agonist (Simonson et al., 2015; Kivell et al., 2018). Mesyl SalB and EOM SalB produce longer-lasting analgesia in a warm-water tail-withdrawal rodent assay than SalA, without aversion, anxiety, or depressive-like effects (Ewald et al., 2017; Paton et al., 2017). Similarly, RB-64 induced analgesia in a hotplate assay in both wild-type and $\beta$-arrestin2 knock-out mice and, at a low dose, did not cause aversionlike responses (White et al., 2015). HS665 and HS666, which are diphenethylamine derivatives, exhibit great affinity for KORs and very weak partial agonism for $\beta$-arrestin- 2 signaling. These compounds elicited a potent dose-dependent analgesic effect in the warm-water tail-withdrawal assay when administrated intracerebroventricularly (Spetea et al., 2012, 2017) and had no effect on locomotor behavior or aversion (Erli et al., 2017). A different study showed that both agents display analgesic action in an acetic acid writhing assay when injected subcutaneously, while demonstrating no motor impairments or sedation (Dunn et al., 2019). Collybolide (Colly) is a very potent biased agonist for treating comorbid pain and psychiatric disorders. Similar to SalA, it has an antinociceptive effect in the tail-flick assay and produces some aversion. However, unlike SalA, Colly exhibits slight antidepressant and anxiogenic effects in the forced swim and open-field tests (Gupta et al., 2016).

\section{Peripherally Restricted KOR Agonists}

Activation of peripheral KORs alone can produce a significant analgesic effect. Thus, the development of peripherally restricted KOR agonists that cannot cross the blood-brain barrier is a viable strategy for avoiding the side effects associated with activation of KORs in the CNS. However, many of the early compounds were ruled out because of insufficient antinociception; researchers were unable to identify effective compounds until recently.

Difelikefalin (CR845) and JNJ-38488502 (CR665) are peripherally restricted tetrapeptide KOR agonists that have shown promising results in preclinical studies, including a reduction in writhing behaviors and inflammatory pain in animal models (Hughes et al., 2013). CR845 is also effective in relieving abdominal pain and mechanical allodynia in a spinal nerve ligation model of neuropathic pain (Beck et al., 2019a). CR845 is currently in phase III clinical trials for the treatment of postoperative pain and uremic pruritus. One of the derivatives of CR665, termed JT09, is currently in development by JT Pharmaceuticals. $20 \mathrm{mg} / \mathrm{kg}$ JT09 administered via oral gavage in rats exhibited similar analgesic effects as $10 \mathrm{mg} / \mathrm{kg}$ morphine, but JT09 showed no sedative or pro-depressive effects in behavioral tests (Beck et al., 2019b). The pharmacodynamics of JT09 and its antinociceptive effects in chronic pain models are still being investigated. There is also a range of peripherally restricted derivatives of nalfurafine that have an increased number of hydrogen bond donors, and these have yielded promising results. These compounds produce dose-dependent anti-allodynic effects in the acetic acid writhing mouse model (Suzuki et al., 2017). Further work is planned to fully evaluate the antinociceptive potential of these compounds and assess the side effects. However, whether peripherally restricted KOR agonists can block pain-related depression is still unclear.

\section{KOR Antagonists}

Although it is well known that blockade of KOR activation prevents stress-induced aversive affects, the potential clinical use of KOR antagonists as antidepressants was not addressed until recently. Interestingly, KOR antagonists have been found to play an analgesic role in several injury-free pain studies. For example, stress produces allodynia in many injury-free models of cephalic pain. Microinjections of nor-BNI or CYM51317 (a novel short-acting KOR antagonist) into the CeA in rats prevented this stress-induced allodynia (Xie et al., 2017). 
TABLE 1 | Potential compounds for the treatment of comorbid pain and psychiatric disorders.

\begin{tabular}{|c|c|c|c|c|c|c|}
\hline Compound & Function & $\begin{array}{l}\text { Subjects and } \\
\text { dose: pain } \\
\text { treatment }\end{array}$ & Pain model/paradigm & $\begin{array}{l}\text { Subjects and } \\
\text { dose: } \\
\text { aversion test }\end{array}$ & $\begin{array}{l}\text { Aversive } \\
\text { behavioral } \\
\text { paradigm }\end{array}$ & References \\
\hline Nalfurafine (TRK-820) & $\begin{array}{c}\text { G-protein-biased KOR } \\
\text { agonist }\end{array}$ & $\begin{array}{c}\text { C57BL } / 6 \text { mice } 15 \\
\mu \mathrm{g} / \mathrm{kg}\end{array}$ & Warm-water tail-withdrawal & & & \\
\hline Mesyl SalB & $\begin{array}{c}\text { G-protein-biased KOR } \\
\text { agonist }\end{array}$ & $\begin{array}{l}\text { B6.SJL mice } \\
1 \mathrm{mg} / \mathrm{kg}\end{array}$ & $\begin{array}{l}\text { Intraplantar formaldehyde } \\
\text { (inflammatory pain model), } \\
\text { warm-water tail-withdrawal }\end{array}$ & $\begin{array}{c}\text { SD rat } \\
0.3 \mathrm{mg} / \mathrm{kg}\end{array}$ & $\begin{array}{l}\text { Sucrose self- } \\
\text { administration } \\
\text { CPA CTA }\end{array}$ & $\begin{array}{l}\text { Kivell et al., } \\
2018\end{array}$ \\
\hline EOM SalB & $\begin{array}{c}\text { G-protein-biased KOR } \\
\text { agonist }\end{array}$ & $\begin{array}{l}\text { C57BL/6J mice } \\
0.1,0.3 \mathrm{mg} / \mathrm{kg}\end{array}$ & Warm-water tail-withdrawal & $\begin{array}{l}\text { SD rat } 0.1 \\
0.3 \mathrm{mg} / \mathrm{kg}\end{array}$ & CPA EPM FST & $\begin{array}{l}\text { Ewald et al., } \\
\text { 2017; Paton } \\
\text { et al., } 2017\end{array}$ \\
\hline RB-64 & $\begin{array}{c}\text { G-protein-biased KOR } \\
\text { agonist }\end{array}$ & $\begin{array}{l}\text { C57BL/6 mice 3, } \\
10 \mathrm{mg} / \mathrm{kg}\end{array}$ & Hotplate analgesia & $\begin{array}{l}\text { C57BL/6 mice } \\
3 \mathrm{mg} / \mathrm{kg}\end{array}$ & CPA & $\begin{array}{l}\text { White et al., } \\
\text { 2014; White } \\
\text { et al., } 2015\end{array}$ \\
\hline \multirow[t]{2}{*}{ HS665 } & $\begin{array}{c}\text { G-protein biased KOR } \\
\text { agonist }\end{array}$ & $\begin{array}{l}\text { C57BL/6J mice 10, } \\
30 \text { nmol, i. c.v. }\end{array}$ & Warm-water tail-withdrawal & $\begin{array}{l}\text { C57BL/6J mice } \\
\text { 10, } 30 \mathrm{nmol}, \\
\text { i.c.v. }\end{array}$ & $\begin{array}{l}\text { CPA (have } \\
\text { aversion) }\end{array}$ & $\begin{array}{l}\text { Spetea et al., } \\
2017\end{array}$ \\
\hline & & $\begin{array}{c}\text { C57BL/6J mice } 30 \\
\text { nmol, i. c.v. }\end{array}$ & $\begin{array}{c}\text { Acetic acid-induced } \\
\text { writhing }\end{array}$ & & & $\begin{array}{l}\text { Spetea et al., } \\
2012\end{array}$ \\
\hline HS666 & $\begin{array}{c}\text { G-protein-biased KOR } \\
\text { agonist }\end{array}$ & $\begin{array}{l}\text { C57BL/6J mice 10, } \\
30 \text { nmol, i. c.v. }\end{array}$ & $\begin{array}{c}\text { Acetic acid-induced } \\
\text { writhing }\end{array}$ & $\begin{array}{l}\text { C57BL/6J mice } \\
30 \text { nmol, i.c.v. }\end{array}$ & CPA & $\begin{array}{l}\text { Spetea et al., } \\
2012\end{array}$ \\
\hline Collybolide & $\begin{array}{c}\text { G-protein-biased KOR } \\
\text { agonist }\end{array}$ & $\begin{array}{l}\text { C57BL/6J mice } \\
2 \mathrm{mg} / \mathrm{kg}\end{array}$ & Tail flick test & $\begin{array}{l}\text { C57BL/6J mice } \\
2 \mathrm{mg} / \mathrm{kg}\end{array}$ & CPA FST EPM & $\begin{array}{l}\text { Gupta et al., } \\
2016\end{array}$ \\
\hline \multirow[t]{2}{*}{ Difelikefalin (CR845) } & $\begin{array}{c}\text { Peripherally restricted } \\
\text { KOR agonist }\end{array}$ & $\begin{array}{l}\text { C57BL/6J mice } \\
10 \mathrm{mg} / \mathrm{kg}\end{array}$ & $\begin{array}{c}\text { Spinal nerve ligation } \\
\text { (neuropathic pain model) }\end{array}$ & $\begin{array}{l}\text { C57BL/6J mice } \\
10 \mathrm{mg} / \mathrm{kg}\end{array}$ & OFT & $\begin{array}{l}\text { Beck et al., } \\
2019 a\end{array}$ \\
\hline & & $\begin{array}{l}\text { Human clinical III } \\
\text { phase }\end{array}$ & Postoperative pain & & & $\begin{array}{l}\text { Gardell et al., } \\
2008\end{array}$ \\
\hline JNJ-38488502 (CR665) & $\begin{array}{c}\text { Peripherally restricted } \\
\text { KOR agonist }\end{array}$ & $\mathrm{SD}$ rat $20 \mathrm{mg} / \mathrm{kg}$ & $\begin{array}{l}\text { Acetic acid-induced } \\
\text { writhing. hot plate analgesia }\end{array}$ & $\begin{array}{c}\text { SD rat } \\
20 \mathrm{mg} / \mathrm{kg}\end{array}$ & OFT & $\begin{array}{l}\text { Hughes et al., } \\
2013\end{array}$ \\
\hline JT09 & $\begin{array}{l}\text { Peripherally restricted } \\
\text { KOR agonist }\end{array}$ & $\mathrm{SD}$ rat $10 \mathrm{mg} / \mathrm{kg}$ & $\begin{array}{l}\text { Acetic acid-induced } \\
\text { writhing. hot plate analgesia }\end{array}$ & $\begin{array}{c}\text { SD rat } \\
20 \mathrm{mg} / \mathrm{kg}\end{array}$ & CPA FST & $\begin{array}{l}\text { Beck et al., } \\
\text { 2019b }\end{array}$ \\
\hline Nor-BNI & KOR antagonist & $\begin{array}{c}\text { C57BL/6J mice } \\
3 \mathrm{mg} / \mathrm{kg}, \text { s.c } 2.5 \\
\mu \mathrm{g} / \text { lateral }\end{array}$ & $\begin{array}{l}\text { Cephalic and extracephalic } \\
\text { cutaneous allodynia, tail } \\
\text { flick test }\end{array}$ & $\begin{array}{l}\text { C57BL/6J mice } \\
\text { SD rat }\end{array}$ & CPA FST EPM & $\begin{array}{l}\text { Xie et al., 2017; } \\
\text { Page et al., } \\
2019\end{array}$ \\
\hline CYM-51317 & KOR antagonist & $\begin{array}{c}\text { C57BL/6J mice } \\
20 \mathrm{mg} / \mathrm{kg} 1 \\
\mu \mathrm{g} / \text { lateral }\end{array}$ & $\begin{array}{c}\text { Cephalic and extracephalic } \\
\text { cutaneous allodynia, tail } \\
\text { flick test }\end{array}$ & & & Xie et al., 2017 \\
\hline CYM-53093 & KOR antagonist & $\begin{array}{l}\text { C57BL/6J mice } \\
10 \mathrm{mg} / \mathrm{kg}\end{array}$ & Tail flick-test migraine & & & $\begin{array}{l}\text { Guerrero et al., } \\
2019\end{array}$ \\
\hline Buprenorphine & $\begin{array}{l}\text { Partial MOR agonist } \\
\text { and KOR antagonist }\end{array}$ & Human (1-4 mg/d) & $\begin{array}{c}\text { Postoperative moderate to } \\
\text { severe pain }\end{array}$ & $\begin{array}{l}\text { Older adults } \\
0.4 \mathrm{mg} / \mathrm{d}\end{array}$ & $\begin{array}{c}\text { Montgomery- } \\
\text { Asberg } \\
\text { Depression } \\
\text { Rating scale }\end{array}$ & $\begin{array}{l}\text { Karp et al., } \\
\text { 2014; Yovell } \\
\text { et al., } 2016\end{array}$ \\
\hline
\end{tabular}

CPA, conditioned place aversion; CTA, conditioned taste aversion; EPM, elevated plus maze; FST, forced swim test.

Similarly, oral administration of CYM-53093 had a protective effect against migraine (Guerrero et al., 2019).

Using compounds which are both antagonistic to KORs and agonistic to other opioid receptors may be another good choice for treating comorbid pain and psychiatric disorders. Buprenorphine, a partial MOR agonist and KOR antagonist that provides long-lasting analgesia for chronic pain, is a promising candidate. It has been investigated for its anti-depression potential in preclinical studies and clinical trials and produced a rapid and sustained improvement in elders with resistant depression, even at a low dose. Furthermore, an early open-label study reported that buprenorphine alleviates negative symptoms in patients with treatment-refractory, unipolar, non-psychotic, major depression (Karp et al., 2014; Yovell et al., 2016).

\section{CONCLUSION}

Over the past decades, information has accumulated about the pathophysiological and pharmacological implications of the role of the Dyn/KOR system in the comorbidity of chronic pain and mood disorders. The Dyn/KOR system mediates paininduced aversive states by regulating many aspects of emotion processing, including DA neurotransmission of the mesolimbic circuitry, the efficacy of the CeA-lPBN pathway, and the intrinsic excitability of 5-HT neurons. A new generation of biased KOR agonists together with new clinical medication strategies has led to a focus on KORs as a potential drug target for pain and psychiatric disorders with fewer side effects. These studies have increased our understanding of how the Dyn/KOR system 
is involved in pain and mood disorders and have revealed promising therapeutic targets for the treatment of comorbid pain and psychiatric disorders.

\section{AUTHOR CONTRIBUTIONS}

M-JJ, JY, and Z-QG drafted the manuscript. CL critically edited the manuscript. LZ contributed substantially to the manuscript revision. All authors approved the manuscript in its final form.

\section{REFERENCES}

Abraham, A. D., Schattauer, S. S., Reichard, K. L., Cohen, J. H., Fontaine, H. M., Song, A. J., et al. (2018). Estrogen regulation of GRK2 inactivates kappa opioid receptor signaling mediating analgesia, but not aversion. J. Neurosci. 38, 8031-8043. doi: 10.1523/jneurosci.0653-18.2018

Avidor-Reiss, T., Nevo, I., Saya, D., Bayewitch, M., and Vogel, Z. (1997). Opiateinduced adenylyl cyclase superactivation is isozyme-specific. J. Biol. Chem. 272, 5040-5047. doi: 10.1074/jbc.272.8.5040

Bair, M. J., Robinson, R. L., Katon, W., and Kroenke, K. (2003). Depression and pain comorbidity: a literature review. Arch. Intern. Med. 163, 2433-2445. doi: 10.1001/archinte.163.20.2433

Beck, T. C., Hapstack, M. A., Beck, K. R., and Dix, T. A. (2019a). Therapeutic potential of kappa opioid agonists. Pharmaceuticals (Basel) 12:95. doi: 10.3390/ ph12020095

Beck, T. C., Reichel, C. M., Helke, K. L., Bhadsavle, S. S., and Dix, T. A. (2019b). Non-addictive orally active kappa opioid agonists for the treatment of peripheral pain in rats. Eur. J. Pharmacol. 856:172396. doi: 10.1016/j.ejphar. 2019.05.025

Browne, C. A., Falcon, E., Robinson, S. A., Berton, O., and Lucki, I. (2018). Reversal of stress-induced social interaction deficits by buprenorphine. Int. J. Neuropsychopharmacol. 21, 164-174. doi: 10.1093/ijnp/pyx079

Bruchas, M. R., Xu, M., and Chavkin, C. (2008). Repeated swim stress induces kappa opioid-mediated activation of extracellular signal-regulated kinase 1/2. Neuroreport 14, 1417-1422. doi: 10.1097/wnr.0b013e32830dd655

Buda, J. J., Carroll, F. I., Kosten, T. R., Swearingen, D., and Walters, B. B. (2015). A double-blind, placebo-controlled trial to evaluate the safety, tolerability, and pharmacokinetics of single, escalating oral doses of JDTic. Neuropsychopharmacology 40, 2059-2065. doi: 10.1038/npp.2015.27

Cahill, C. M., Taylor, A. M., Cook, C., Ong, E., Moron, J. A., and Evans, C. J. (2014). Does the kappa opioid receptor system contribute to pain aversion? Front. Pharmacol. 5:253. doi: 10.3389/fphar.2014.00253

Carr, G. V., Bangasser, D. A., Bethea, T., Young, M., Valentino, R. J., and Lucki, I. (2010). Antidepressant-like effects of kappa-opioid receptor antagonists in wistar kyoto rats. Neuropsychopharmacology 35, 752-763. doi: 10.1038/npp. 2009.183

Carrasquillo, Y., and Gereau, R. W. (2008). Hemispheric lateralization of a molecular signal for pain modulation in the amygdala. Mol. Pain 4:24.

Chartoff, E. H., and Mavrikaki, M. (2015). Sex differences in kappa opioid receptor function and their potential impact on addiction. Front. Neurosci. 9:466. doi: $10.3389 /$ fnins.2015.00466

Chavkin, C., and Koob, G. F. (2016). Dynorphin, dysphoria, and dependence: the stress of addiction. Neuropsychopharmacology 41, 373-374. doi: 10.1038/npp. 2015.258

Chavkin, C., and Martinez, D. (2015). Kappa antagonist JDTic in phase 1 clinical trial. Neuropsychopharmacology 40, 2057-2058. doi: 10.1038/npp.2015.74

Chiang, M. C., Nguyen, E. K., Canto-Bustos, M., Papale, A. E., Oswald, A. M. M., and Ross, S. E. (2020). Divergent neural pathways emanating from the lateral parabrachial nucleus mediate distinct components of the pain response. Neuron 106, 927-939. doi: 10.1016/j.neuron.2020.03.014

Crofford, L. J. (2010). Adverse effects of chronic opioid therapy for chronic musculoskeletal pain. Nat. Rev. Rheumatol. 6, 191-197. doi: 10.1038/nrrheum. 2010.24

\section{FUNDING}

This work was supported by a general project (grant no. 81974157) and a youth project (grant no. 81901369) from the Natural Science Foundation of China, a Jiangsu Special Appointed Professorship (to CL) from the Jiangsu Education Department, an Introduction Plan of High Level Innovative and Entrepreneurial Talents in Jiangsu Province to M-JJ, and starting grants of excellent talents (grant nos. D2019025 and D2019021) from Xuzhou Medical University, Xuzhou, China.

Darcq, E., and Kieffer, B. L. (2018). Opioid receptors: drivers to addiction? Nat. Rev. Neurosci. 8, 499-514. doi: 10.1038/s41583-018-0028-x

Dunn, A., Reed, B., Erazo, J., Ben-Ezra, A., and Kreek, M. J. (2019). Signaling properties of structurally diverse kappa opioid receptor ligands: towards in vitro models of in vivo responses. ACS Chem. Neurosci. 10, 3590-3600. doi: 10.1021/ acschemneuro.9b00195

Ehrich, J. M., Messinger, D. I, Knakal, C. R., Kuhar, J. R., Schattauer, S. S., et al. (2015). Kappa opioid receptor-induced aversion requires p38 mapk activation in VTA dopamine neurons. J. Neurosci. 35, 12917-12931. doi: 10. 1523/jneurosci.2444-15.2015

Erli, F., Guerrieri, E., Ben Haddou, T., Lantero, A., Mairegger, M., Schmidhammer, H., et al. (2017). Highly potent and selective new diphenethylamines interacting with the $\kappa$-opioid receptor: synthesis, pharmacology, and structure-activity relationships. J. Med. Chem. 60, 7579-7590. doi: 10.1021/acs.jmedchem. $7 \mathrm{~b} 00981$

Ewald, A. M., Bosch, P. J., Culverhouse, A., Crowley, R. S., Neuenswander, B., and Prisinzano, T. E. (2017). The C-2 derivatives of salvinorin A, ethoxymethyl ether Sal B and beta-tetrahydropyran Sal B, have anti-cocaine properties with minimal side effects. Psychopharmacology (Berl) 234, 2499-2514. doi: 10.1007/ s00213-017-4637-2

Fallon, J. H., Leslie, F. M., and Cone, R. I. (1985). Dynorphin-containing pathways in the substantia nigra and ventral tegmentum: a double labeling study using combined immunofluorescence and retrograde tracing. Neuropeptides 5, 457460. doi: 10.1016/0143-4179(85)90053-8

Fields, H. L. (2011). The doctor's dilemma: opiate analgesics and chronic pain. Neuron 69, 591-594. doi: 10.1016/j.neuron.2011.02.001

Fuentealba, J. A., Gysling, K., and Andrés, M. E. (2010). Repeated treatment with the kappa-opioid agonist U-69593 increases $\mathrm{K}+$-stimulated dopamine release in the rat medial prefrontal cortex. Synapse 64, 898-904. doi: 10.1002/syn.20808

Gardell, L. R., Ma, J. N., Seitzberg, J. G., Knapp, A. E., Schiffer, H. H., Tabatabaei, A., et al. (2008). Identification and characterization of novel small-molecule protease-activated receptor 2 agonist. J. Pharmacl. Exp. Ther. 327, 799-808. doi: 10.1124/jpet.108.142570

Graziane, N. M., Polter, A. M., Briand, L. A., Pierce, R. C., and Kauer, J. A. (2013). Kappa opioid receptors regulate stress-induced cocaine seeking and synaptic plasticity. Neuron 77, 942-954. doi: 10.1016/j.neuron.2012.12.034

Guan, X. H., Lu, X. F., Zhang, H. X., Wu, J. R., Yuan, Y., Bao, Q., et al. (2010). Phosphatidylinositol 3-kinase mediates pain behaviors induced by activation of peripheral ephrinBs/EphBs signaling in mice. Pharmacol. Biochem. Behav. 95, 315-324. doi: 10.1016/j.pbb.2010.02.007

Guerrero, M., Urbano, M., Kim, E.-K., Gamo, A. M., Riley, S., and Abgaryan, L. (2019). Design and synthesis of a novel and selective kappa opioid receptor (KOR) antagonist (BTRX-335140). J. Med. Chem. 62, 1761-1780. doi: 10.1021/ acs.jmedchem. $8 \mathrm{~b} 01679$

Gupta, A., Gomes, I., Bobeck, E. N., Fakira, A. K., Massaro, N. P., Sharma, I., et al. (2016). Collybolide is a novel biased agonist of $\kappa$-opioid receptors with potent antipruritic activity. Proc. Natl. Acad. Sci. U S A. 113, 6041-6046. doi: $10.1073 /$ pnas. 1521825113

Hjelmstad, G. O., and Fields, H. L. (2003). Kappa opioid receptor activation in the nucleus accumbens inhibits glutamate and GABA release through different mechanisms. J. Neurophysiol. 89, 2389-2395. doi: 10.1152/jn.01115.2002

Howe, C. Q., and Sullivan, M. D. (2014). The missing "P" in pain management: how the current opioid epidemic highlights the need for psychiatric services 
in chronic pain care. Gen. Hosp. Psychiatry 36, 99-104. doi: 10.1016/j. genhosppsych.2013.10.003

Hudmon, A., Choi, J. S., Tyrrell, L., Black, J. A., Rush, A. M., Waxman, S. G., et al. (2008). Phosphorylation of sodium channel $\mathrm{Na}(\mathrm{v}) 1.8$ by p38 mitogen-activated protein kinase increases current density in dorsal root ganglion neurons. $J$ Neurosci 28, 3190-3201. doi: 10.1523/jneurosci.4403-07.2008

Hughes, F. M., Shaner, B. E., Brower, J. O., Woods, R. J., and Dix, T. A. (2013). Development of apeptide-derived orally-active kappa-opioid receptor agonist targeting peripheral pain. Open Med Chem J 7, 16-22. doi: 10.2174/ 1874104501307010016

Hwa, L. S., Neira, S., Flanigan, M. E., Stanhope, C. M., Pina, M. M., Pati, D., et al. (2020). Alcohol drinking alters stress response to predator odor via BNST kappa opioid receptor signaling in male mice. eLife 9:e59709.

Ji, N. N., Kang, J., Hua, R., and Zhang, Y. M. (2018). Involvement of dopamine system in the regulation of the brain corticotropin-releasing hormone in paraventricular nucleus in a rat model of chronic visceral pain. Neurol. Res. 8, 650-657.

Karp, J. F., Butters, M. A., Begley, A. E., Miller, M. D., Lenze, E. J., Blumberger, D. M., et al. (2014). Safety, tolerability, and clinical effect of low-dose buprenorphine for treatment resistant depression in midlife and older adults. J. Clin. Psychiatry 75, e785-e793.

Kaufling, J., Girard, D., Maitre, M., Leste-Lasserre, T., and Georges, F. (2017). Species-specific diversity in the anatomical and physiological organisation of the BNST-VTA pathway. Eur. J. Neurosci. 45, 1230-1240. doi: 10.1111/ejn. 13554

Kivell, B., Paton, K., Kumar, N., Morani, A., Culverhouse, A., Shepherd, A., et al. (2018). Kappa opioid receptor agonist mesylsal b attenuates behavioral sensitization to cocaine with fewer aversive side effects than salvinorin a in rodents. Molecules 23:2602. doi: 10.3390/molecules 23102602

Kravets, J. L., Reyes, B. A., Unterwald, E. M., and van Bockstaele, E. J. (2015). Direct targeting of peptidergic amygdalar neurons by noradrenergic a?erents: linking stress-integrative circuitry. Brain Struct. Funct. 220, 541-558. doi: 10. 1007/s00429-013-0674-8

Kumagai, H., Ebata, T., Takamori, K., Muramatsu, T., Nakamoto, H., and Suzuki, H. (2010). Effect of a novel kappa-receptor agonist, nalfurafine hydrochloride, on severe itch in 337 haemodialysis patients: a Phase III, randomized, doubleblind, placebo-controlled study. Nephrol. Dial. Transplant. 25, 1251-1257. doi: 10.1093/ndt/gfp588

Land, B. B., Bruchas, M. R., Schattauer, S., Giardino, W. J., Aita, M., Messinger, D., et al. (2009). Activation of the kappa opioid receptor in the dorsal raphe nucleus mediates the aversive effects of stress and reinstates drug seeking. Proc. Natl. Acad. Sci. U S A. 106, 19168-19173. doi: 10.1073/pnas.0910705106

Leite-Almeida, H., Pinto-Ribeiro, F., and Almeida, A. (2015). Animal models for the study of comorbid pain and psychiatric disorders. Mod. Trends Pharmacopsychiatry 30, 1-21. doi: 10.1159/000435929

Lemos, J. C., Roth, C. A., Messinger, D. I., Gill, H. K., Phillip, P. E., and Chavkin, C. (2012). Repeated stress dysregulates kappa opioid receptor signaling in the dorsal raphe through a p38 $\alpha$ MAPK dependent mechanism. J. Neurosci. 32, 12325-12336. doi: 10.1523/jneurosci.2053-12.2012

Li, C., Pleil, K. E., Stamatakis, A. M., Busan, S., Vong, L., Lowell, B. B., et al. (2012). Presynaptic inhibition of GABA release in the BNST by kappa opioid receptor signaling. Biol. Psychiatry 71, 725-732. doi: 10.1016/j.biopsych.2011.11.015

Li, J., Li, J. G., Chen, C., Zhang, F., and Liu-Chen, L. Y. (2002). Molecular basis of differences in (-)(trans)-3,4-dichloroN-methyl-N-[2-(1-pyrrolidiny)cyclohexyl]benzeneacetamide-induced desensitization and phosphorylation between human and rat kappa-opioid receptors expressed in Chinese hamster ovary cells. Mol. Pharmacol. 61, 73-84. doi: 10.1124/mol.61.1.73

Liu, S. W., Pichens, S., Burma, N. E., Lecue, I. I., Yang, H. Y., Xue, L. H., et al. (2019). Kappa opioid receptors drive a tonic aversive component of chronic pain. J. Neuronsci. 39, 4162-4178. doi: 10.1523/jneurosci.0274-19.2019

Lowe, S. L., Wong, C. J., Witcher, J., Gonzales, C. R., Dickinson, G. L., Bell, R. L., et al. (2014). Safety, tolerability, and pharmacokinetic evaluation of singleand multiple-ascending doses of a novel kappa opioid receptor antagonist LY2456302 and drug interaction with ethanol in healthy subjects. J. Clin. Pharmacol. 54, 968-978. doi: 10.1002/jcph.286

Lowery-Gionta, E. G., Crowley, N. A., Bukalo, O., Silverstein, S., Holmes, A., and Kash, T. L. (2018). Chronic stress dysregulates amygdalar output to the prefrontal cortex. Neuropharmacology 139, 68-75. doi: 10.1016/j.neuropharm. 2018.06.032

Marchant, N. J., Densmore, V. S., and Osborne, P. B. (2007). Coexpression of prodynorphin and corticotrophin-releasing hormone in the rat central amygdala: evidence of two distinct endogenous opioid systems in the lateral division. J. Comp. Neurol. 504, 702-715. doi: 10.1002/cne.21464

Margolis, E. B., Lock, H., Chefer, V. I., Shippenberg, T. S., Hjelmstad, G. O., and Fields, H. L. (2006). Kappa opioids selectively control dopaminergic neurons projecting to the prefrontal cortex. Proc. Natl. Acad. Sci. U S A. 103, 2938-2942. doi: 10.1073/pnas.0511159103

Margolis, E. B., Mitchell, J. M., Ishikawa, J., Hjelmstad, G. O., and Fields, H. L. (2008). Midbrain dopamine neurons: projection target determines action potential duration and dopamine D (2) receptor inhibition. J. Neurosci. 28, 8908-8913. doi: 10.1523/jneurosci.1526-08.2008

Martinez, D., Slifstein, M., Matuskey, D., Nabulsi, N., Zheng, M. Q., and Lin, S. (2019). Kappa-opioid receptors, dynorphin and cocaine addiction: a positron emission tomography study. Neuropsychopharmacology 44, 1720-1727. doi: 10.1038/s41386-019-0398-4

Massaly, N., Copits, B. A., Wilson-Poe, A. R., Hipolito, L., Markovic, T., and Yoon, H. J. (2019). Pain-induced negative affect is mediated via recruitment of the nucleus accumbens kappa opioid system. Neuron 102, 564-573. doi: 10.1016/j.neuron.2019.02.029

McLennan, G. P., Kiss, A., Miyatake, M., Belcheva, M. M., Chambers, K. T., Pozek, J. J., et al. (2008). Kappa opioids promote the proliferation of astrocytes via Gbetagamma and beta-arrestin 2-dependent MAPK-mediated pathways. J. Neurochem. 107, 1753-1765. doi: 10.1111/j.1471-4159.2008.05745.x

Meade, J. A., Alkhlaif, Y., Contreras, K. M., Obeng, S., Toma, W., Sim-Selley, L. J., et al. (2020). Kappa opioid receptors mediate an initial aversive component of paclitaxel-induced neuropathy. Psychopharmacology (Berl) 237, 2777-2793. doi: $10.1007 /$ s00213-020-05572-2

Nation, K. M., DeFelice, M., Hernandez, P. I., Dodick, D. W., Volker, N., Navratilova, E., et al. (2018). Lateralized kappa opioid receptor signaling from the amygdale central nucleus promotes stress-induced functional pain. Pain 159, 919-928. doi: 10.1097/j.pain.0000000000001167

Navratilova, E., Ji, G., Phelps, C., Qu, C., Hein, M., Yakhnitsa, V., et al. (2019). Kappa opioid signaling in the central nucleus of the amygdala promotes disinhibition and aversiveness of chronic neuropathic pain. Pain 160, 824-832. doi: 10.1097/j.pain.0000000000001458

Navratilova, E., Xie, J. Y., Okun, A., Qu, C., Eyde, N., Ci, S., et al. (2012). Pain relief produces negative reinforcement through activation of mesolimbic rewardvaluation circuitry. Proc. Natl. Acad. Sci. U S A. 109, 20709-20713. doi: 10. 1073/pnas.1214605109

Page, S., Mavrikaki, M. M., Lintz, T., Puttick, D., Roberts, E., Rosen, H., et al. (2019). Behavioral pharmacology of novel kappa opioid receptor antagonists in rats. Int. J. Neuropsychopharmacol. 22, 735-745.

Palmisano, M., Mercatelli, D., Caputi, F. F., Carretta, D., Romualdi, P., and Candeletti, S. (2017). N/OFQ system in brain areas of nerve-injured mice: its role in different aspects of neuropathic pain. Genes Brain Behav. 16, 537-545. doi: $10.1111 / \mathrm{gbb} .12365$

Paton, K. F., Kumar, N., Crowley, R. S., Harper, J. L., Prisinzano, T. E., and Kivell, B. M. (2017). The analgesic and anti-inflammatory effects of salvinorin a analogue betatetrahydropyran Salvinorin B in mice. Eur. J. Pain 21, 1039-1050. doi: 10.1002/ejp.1002

Peckys, D., and Hurd, Y. L. (2001). Prodynorphin and kappa opioid receptor mRNA expression in the cingulate and prefrontal cortices of subjects diagnosed with schizophrenia or affective disorders. Brain Res. Bull. 55, 619-624. doi: 10.1016/s0361-9230(01)00525-1

Raver, C., Uddin, O., Ji, Y. D., Li, Y., Cramer, N., Jenne, C., et al. (2020). Anamygdalo-parabrachial pathway regulates pain perception and chronic pain. J. Neurosci. 40, 3424-3442. doi: 10.1523/jneurosci.0075-20.2020

Raynor, K., Kong, H., Hines, J., Kong, G., Benovic, J., Yasuda, K., et al. (1994). Molecular mechanisms of agonist-induced desensitization of the cloned mouse kappa opioid receptor. J. Pharmacol. Exp. Ther. 270, 1381-1386.

Ruan, J. P., Zhang, H. X., Lu, X. F., Liu, Y. P., and Cao, J. L. (2010). EphrinBs/EphBs signaling is involved in modulation of spinal nociceptive processing through a mitogen-activated protein kinases-dependent mechanism. Anesthesiology 112, 1234-1249. doi: 10.1097/aln.0b013e3181d3e0df 
Rusin, K. I., Giovannucci, D. R., Stuenkel, E. L., and Moises, H. C. (1997). Kappaopioid receptor activation modulates $\mathrm{Ca} 2+$ currents and secretion in isolated neuroendocrine nerve terminals. J. Neurosci. 17, 6565-6574. doi: 10.1523/ jneurosci.17-17-06565.1997

Russell, S. E., Rachlin, A. B., Smith, K. L., Muschamp, J., Berry, L., Zhao, Z., et al. (2014). Sex differences in sensitivity to the depressive-like effects of the kappa opioid receptor agonist U-50488 in rats. Biol. Psychiatry 76, 213-222. doi: 10.1016/j.biopsych.2013.07.042

Sadja, R., Alagem, N., and Reuveny, E. (2003). Gating of GIRK channels: details of an intricate, membrane-delimited signaling complex. Neuron 39, 9-12. doi: 10.1016/s0896-6273(03)00402-1

Salas, J., Scherrer, J. F., and Schneider, F. D. (2017). New-onset depression following stable, slow, and rapid rate of prescription opioid dose escalation. Pain 158, 306-312. doi: 10.1097/j.pain.0000000000000763

Schattauer, S. S., Kuhar, J. R., Song, A., and Chavkin, C. (2017). Nalfurafine is a G-protein biased agonist having significantly greater bias at the human than rodent form of the kappa opioid receptor. Cell. Signal. 32, 59-65. doi: 10.1016/ j.cellsig.2017.01.016

Scherrer, J. F., Salas, J., Copeland, L. A., Stock, E. M., Ahmedani, B. K., Sullivan, M. D., et al. (2016). Prescription opioid duration, dose, and increased risk of depression in 3 large patient populations. Anna. Family Med. 1, 54-62. doi: 10.1370/afm.1885

Simonson, B., Morani, A. S., Ewald, A. W., Walker, L., Kumar, N., and Simpson, D. (2015). Pharmacology and anti-addiction effects of the novel kappa opioid receptor agonist Mesyl Sal B, a potent and long-acting analogue of salvinorin A. Br. J. Pharmacol. 172, 515-531. doi: 10.1111/bph.12692

Snyder, L. M., Chiang, M. C., Loeza-Alcocer, E., Omori, Y., Hachisuka, J., and Sheahan, T. D. (2018). Kappa opioid receptor distribution and function in primary afferents. Neuron $99,1274-1288$.

Spanagel, R., Herz, A., and Shippenberg, T. S. (1992). Opposing tonically active endogenous opioid systems modulate the mesolimbic dopaminergic pathway. Proc. Natl. Acad. Sci. U S A. 89, 2046-2050. doi: 10.1073/pnas.89.6. 2046

Spetea, M., Berzetei-Gurske, I. P., Guerrieri, E., and Schmidhammer, H. (2012). Discovery and pharmacological evaluation of a diphenethylamine derivative (HS665), a highly potent and selective kappa opioid receptor agonist. J. Med. Chem. 55, 10302-10306. doi: 10.1021/jm301258w

Spetea, M., Eans, S. O., Ganno, M. L., Lantero, A., Mairegger, M., Toll, L., et al. (2017). Selective kappa receptor partial agonist HS666 produces potent antinociception without inducing aversion after i.c.v. administration in mice. Br. J. Pharmacol. 174, 2444-2456. doi: 10.1111/bph.13854

Steiner, J. A., Carneiro, A. M., and Blakely, R. D. (2008). Going with the flow: trafficking-dependent and-independent regulation of serotonin transport. Traffic 9, 1393-1402. doi: 10.1111/j.1600-0854.2008.00757.x

Sullivan, M. D. (2016). Why does depression promote long-term opioid use? Pain 157, 2395-2396. doi: 10.1097/j.pain.0000000000000658

Suzuki, S., Sugawara, Y., Inada, H., Tsuji, R., Inoue, A., and Tanimura, R. (2017). Discovery of peripheral kappa opioid receptor agonists as novel analgesics. Chem. Pharm. Bull. (Tokyo) 65, 1085-1088.

Tejeda, H. A., Counotte, D. S., Oh, E., Ramamoorthy, S., Schultz-Kuszak, K. N., Backman, C. M., et al. (2013). Prefrontal cortical kappa-opioid receptor modulation of local neurotransmission and conditioned place aversion. Neuropsychopharmacology 38, 1770-1779. doi: 10.1038/npp.2013.76

Tejeda, H. A., Wu, J., Kornspun, A. R., Pignatelli, M., Kashtelyan, V., Krashes, M. J., et al. (2017). Pathway- and cell-specific kappa-opioid receptor modulation of excitation-inhibition balance differentially gates D1 and D2 accumbens neuron activity. Neuron 93, 147-163. doi: 10.1016/j.neuron.2016.12.005

Thompson, J. M., and Neugebauer, V. (2017). Amygdala plasticity and pain. Pain Res. Manag. 1:8296501.
Thompson, J. M., and Neugebauer, V. (2019). Cortico-limbic pain mechanisms. Neurosci. Lett. 702, 15-23. doi: 10.1016/j.neulet.2018.11.037

Vergara, F., Sardi, N. F., Pescador, A. C., Stern, C. A. J., Chichorro, J. G., et al. (2020). Contribution of mesolimbic dopamine and kappa opioid systems to the transition from acute to chronic pain. Neuropharmacology 178, 108226-108241. doi: 10.1016/j.neuropharm.2020.108226

Walsh, S. L., Strain, E. C., Abreu, M. E., and Bigelow, G. E. (2001). Enadoline, a selective kappa opioid agonist: comparison with butorphanol and hydromorphone in humans. Psychopharmacology 157, 151-162. doi: 10.1007/ s002130100788

Wawrzczak-Bargiela, A., Ziolkowska, B., Piotrowska, A., Starnowska-Sokol, J., Rojewska, E., Mika, J., et al. (2020). Neuropathic pain dysregulates gene expression of the forebrain opioid and dopamine systems. Neurotox. Res. 37, 800-814. doi: 10.1007/s12640-020-00166-4

White, K. L., Robinson, J. E., Zhu, H., DiBerto, J. F., Polepally, P. R., and Zjawiony, J. K. (2015). The G protein-biased k-opioid receptor agonist rb-64 is analgesic with a unique spectrum of activities in vivo. J. Pharmacol. Exp. Ther. 352, 98-109. doi: 10.1124/jpet.114.216820

White, K. L., Scopton, A. P., Rives, M. L., Bikbulatov, R. V., Polepally, P. R., Brown, P. J., et al. (2014). Identification of novel functionally selective $\kappa$-opioid receptor scaffolds. Mol. Phamacol. 85, 83-90. doi: 10.1124/mol.113.089649

Xie, J. Y., Felice, M. D., Kopruszinski, C. M., Eyde, N., LaVigne, J., Remeniuk, B., et al. (2017). Kappa opioid receptor antagonists: a possible new class of therapeutics for migraine prevention. Cephalalgia 37, 780-794. doi: 10.1177/ 0333102417702120

Xie, J. Y., Qu, C., Patwardhan, A., Ossipov, M. H., Navratilova, E., Becerra, L., et al. (2014). Activation of mesocorticolimbic reward circuits for assessment of relief of ongoing pain: a potential biomarker of efficacy. Pain 155, 1659-1666. doi: 10.1016/j.pain.2014.05.018

Yovell, Y., Bar, G., Mashiah, M., Baruch, Y., Briskman, I., Asherov, J., et al. (2016). Ultra-low-dose buprenorphine as a time-limited treatment for severe suicidal ideation: a randomized controlled trial. Am. J. Psychiatry 173, 491-498. doi: 10.1176/appi.ajp.2015.15040535

Zhang, G. F., Wang, J., Han, J. F., Guo, J., Xie, Z. M., Pan, W., et al. (2016). Acute single dose of ketamine relieves mechanical allodynia and consequent depression-like behaviors in a rat model. Neurosci. Lett. 631,7-12. doi: 10.1016/ j.neulet.2016.08.006

Zhang, M., Liu, Y., Zhao, M., Tang, W., Wang, X., Dong, Z., et al. (2017). Depression and anxiety behaviour in a rat model of chronic migraine. J. Headache Pain 18, 27-40.

Zhang, S., Zhang, H. X., Ku, S. M., Juarez, B., Morel, C., Tzavaras, N., et al. (2018). Sex differences in the neuroadaptations of reward- related circuits in response to subchronic variable stress. Neuroscience 376, 108-116. doi: 10.1016/ j.neuroscience.2018.02.021

Zhou, W. J., Jin, Y., Meng, Q., Zhu, X., Bai, T. J., Tian, Y. H., et al. (2019). A neural circuit for comorbid depressive symptoms in chronic pain. Nat. Nerosci. 22, 1649-1658. doi: 10.1038/s41593-019-0468-2

Conflict of Interest: The authors declare that the research was conducted in the absence of any commercial or financial relationships that could be construed as a potential conflict of interest.

Copyright (c) 2021 Ji, Yang, Gao, Zhang and Liu. This is an open-access article distributed under the terms of the Creative Commons Attribution License (CC BY). The use, distribution or reproduction in other forums is permitted, provided the original author(s) and the copyright owner(s) are credited and that the original publication in this journal is cited, in accordance with accepted academic practice. No use, distribution or reproduction is permitted which does not comply with these terms. 